\title{
BILATERAL GASTROCNEMIUS FLAP FOR HARLEQUIN DEFECTS AROUND THE KNEE
}

\author{
Tarun Chabra ${ }^{1}$, Venkatramani Hari ${ }^{1 *}$, Sabapathy SR ${ }^{1}$ \\ 1. \\ Department of Plastic Surgery, Ganga Medical Centre and Hospitals, 313, Mettupalayam Road, Coimbatore,Tamil Nadu, India
}

\begin{abstract}
Background : Tibial plateau fractures (especially bicondylar Schatzker type 5 and type 6) are a result of high energy trauma. Along with bony component, soft tissue injury is a major determinant in the treatment and final outcome. Bicondylar fractures needs bicolumnar fixation and as such require separate approaches: postero-medial and lateral incisions. The soft tissue of the proximal tibia swells significantly after the injury, coupled with extensive soft tissue dissection during fixation this can lead to subsequent wound breakdown and infection along either side of the proximal tibia which resembles "harlequin eyes". This study describes outcome of management of post operative soft tissue complications following bicolumnar fixation of proximal tibia with medial and lateral gastrocnemius flap. Method : Three patients who had bilateral soft tissue necrosis at surgical incision sites treated with debridement and bilateral gastrocnemius flaps between January 2016 and December 2017 were included in this study. The mean age was 38 years (range 18-50 years) and the mean duration of follow-up was 10 months. Outcome assessments included the condition of the flap and fracture healing time.

Result : All fractures united after surgery. There were no soft tissue complications and all flaps healed well. The mean bony union time was 6 months.

Conclusion: Our technique of covering soft tissue loss at surgical site on medial and lateral side of proximal tibia with bilateral gastrocnemius flap in the same setting is a reliable and safe surgical method for these conditions.
\end{abstract}

Keywords: Gastrocnemius; Harlequin

Latar Belakang: Fraktur tibial plateau (terutama bicondylar Shatzker tipe 5 dan tipe 6) adalah bentuk dari trauma energi tinggi. Seiring dengan komponen tulang, cedera jaringan lunak merupakan penentu utama dalam perawatan dan hasil akhir. Fraktur Bicondylar membutuhkan fiksasi bikolumnar dan karenanya memerlukan pendekatan terpisah: sayatan postero-medial dan lateral. Jaringan lunak tibia proksimal membengkak secara signifikan setelah cedera, ditambah dengan diseksi jaringan lunak yang luas selama fiksasi ini dapat menyebabkan kerusakan luka dan infeksi berikutnya di kedua sisi tibia proksimal yang menyerupai "harlequin eyes". Studi ini menggambarkan hasil dari manajemen komplikasi jaringan lunak pasca operasi setelah fiksasi bikolumnar tibia proksimal dengan flap gastrocnemius medial dan lateral.

Metodologi: Tiga pasien yang memiliki nekrosis jaringan lunak bilateral di lokasi sayatan bedah yang diobati dengan debridement dan flap gastrocnemius bilateral antara Januari 2016 dan Desember 2017 dilibatkan dalam penelitian ini. Usia rata-rata adalah 38 tahun (kisaran 18-50 tahun) dan durasi rata-rata tindak lanjut adalah 10 bulan. Penilaian hasil termasuk kondisi flap dan waktu penyembuhan fraktur.

Hasil: Semua fraktur menyatu setelah operasi. Tidak ada komplikasi jaringan lunak dan semua flap sembuh dengan baik. Waktu penyatuan tulang rata-rata adalah 6 bulan.

Kesimpulan: Teknik kami untuk menutupi kehilangan jaringan lunak di lokasi bedah di sisi medial dan lateral tibia proksimal dengan flap gastrocnemius bilateral dalam pengaturan yang sama adalah metode bedah yang andal dan aman untuk kondisi ini.

Keywords: Gastrocnemius; Harlequin 


\section{INTRODUCTION}

High energy road traffic accident results in extensive lower limb injuries. Bicondylar (Schatzker type 5 and 6) fractures of proximal tibia are commonly seen in our practice. A major concern in treating these fractures is the associated soft tissue injury which becomes a major determining factor in timing of surgery and also final outcome. Bicondylar fractures usually require both posteromedial and lateral approach (standard) for open reduction and internal fixation, anterior incision along margins of tibia in presence of minimal degloving or compartment syndrome. After the injury, soft tissue cover around the proximal tibia swells up significantly. Coupled with extensive soft tissue dissection during fixation this can lead to subsequent wound breakdown and infection along both incisions of the proximal tibia resembling "harlequin eyes". 1-4

Harlequin is the eyes of the joker, also used for describing defects craniofacial deformity not described for this defect before in the literature. Harlequin is a way to describe the defect. It is special as no previous description of such defects as only now we have been using big implants like these in current practice. The peculiarity of these defects is the oblique raw areas extending from midline towards the posterior aspect. No local skin flap option is available and microsurgical free flap also becomes difficult to cover both defects. We describe a technique to cover these bilateral defects over proximal tibia with bilateral gastrocnemius flaps that can be done from posterior midline approach and good mobilization is possible and hence gastrocnemius can be raised comfortably. ${ }^{4-6}$

\section{MATERIALS AND METHOD}

Our study is a retrospective case series in which we have studied three patients with tibial plateau fractures which required dual plating but with subsequent postoperative soft tissue complications along both incisions. We successfully managed the soft tissue problems with debridement and bilateral gastrocnemius flaps. There were no subsequent wound complications and all fractures united in time.

\section{CASE 1:}

55 year diabetic male was involved in a road traffic accident two wheeler vs two wheeler and sustained polytraumatic injuries including a proximal tibia fracture treated with external fixator for a week after the injury as blistering was present. One week after external fixator application, open reduction and plating was done. After open reduction and internal fixation surgical the wound had partial necrosis and with debridement was done after one week of fixation. Once the infection was well controlled and the wound became stable, bilateral gastrocnemius flaps were done. Patient was non weight bearing for one and a half months following the surgery. The flap healed without infection within one month and fracture united by 7 months.

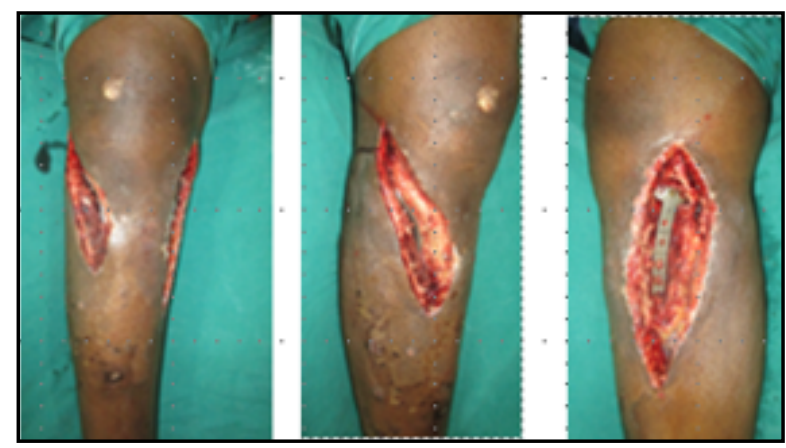

Figure 1: shows case 1 who underwent dual plating and had wound necrosis which was debrided and both the side plates were exposed

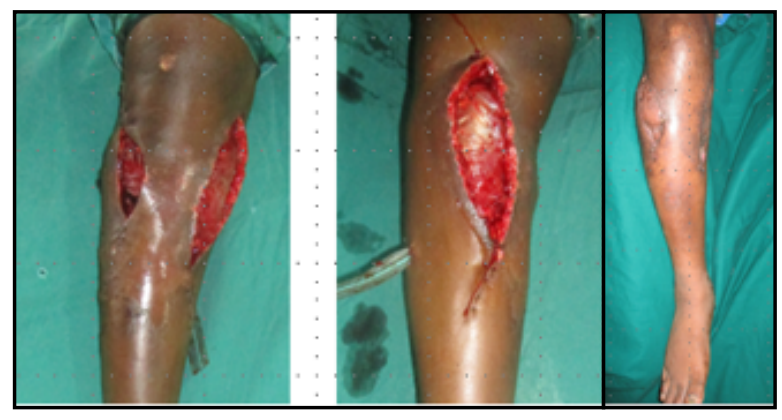

Figure 2 : shows bilateral gastrocnemius flap and then well settled flap after 2 weeks
Disclosure: The authors have no financial interest to disclose. 


\section{CASE 2:}

58 year old diabetic male was involved in a road traffic accident (slip and fall from two wheeler) and was treated elsewhere for his proximal tibial plateau schatzker $\mathrm{V}$ fracture with open reduction and internal fixation with bicolumnar plating. The incisions dehisced and the surgical site became infected and was subsequently referred to our centre. Upon arrival, debridement was performed and after 2 days vacuum assisted closure was applied and changed again in 5 days. Bilateral gastrocnemius flap was done and wound infection was controlled. Bony union at fracture site occurred by 6 months and flap healed well without any further complications.

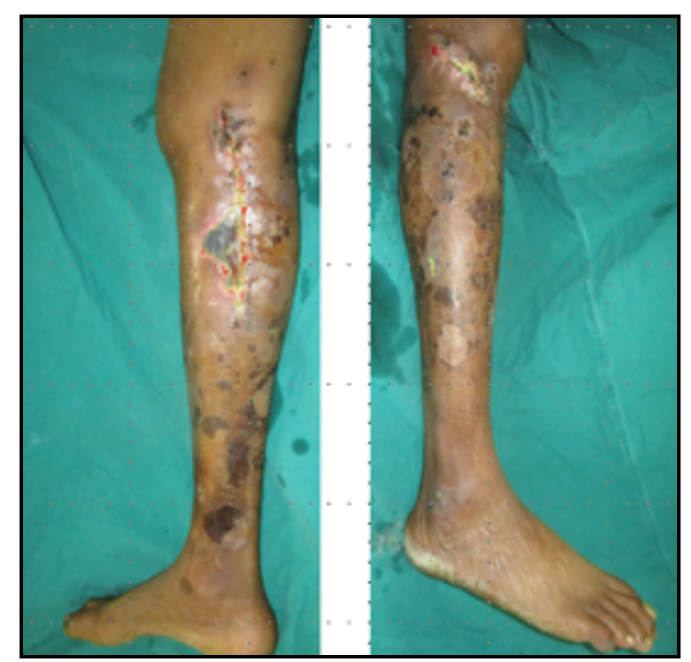

Figure 3 : shows $2^{\text {nd }}$ patient having postoperative wound necrosis at surgical site

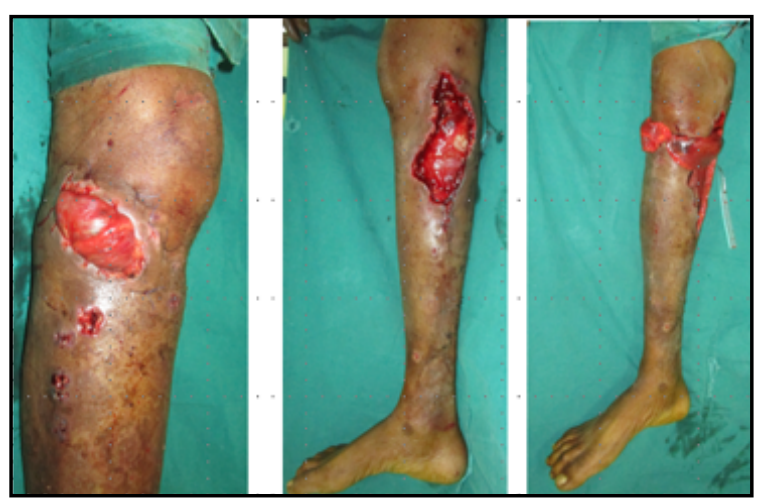

Figure 4: shows placement of bilateral gastrocnemius flap over proximal tibia

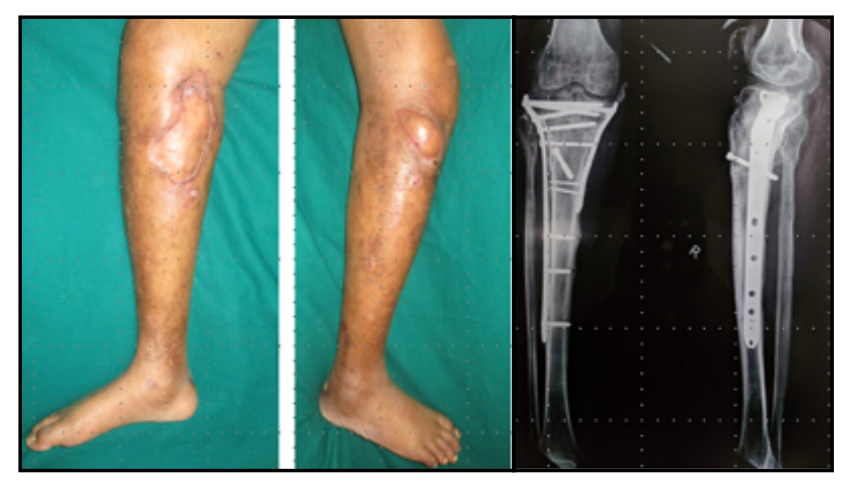

Figure 5: Shows well settled flap on both medial and lateral side and bony union

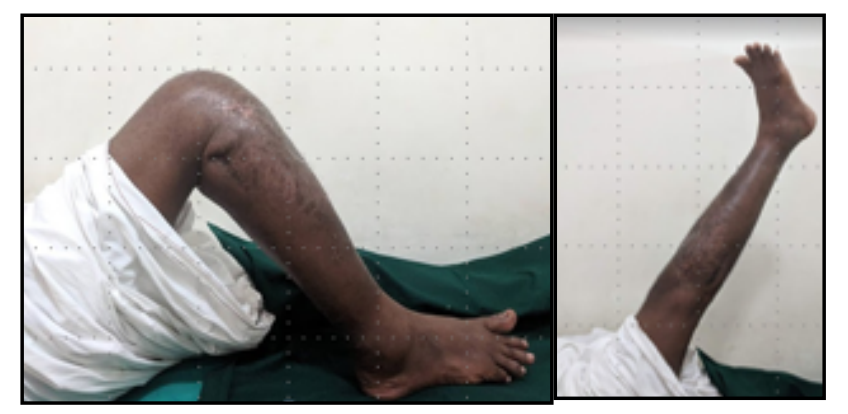

Figure 6: Shows good range (till 90 degree of knee flexion ) of motion after 1 year of last procedure

\section{CASE 3:}

48 year male sustained a fall from a two wheeler and resulting in a closed proximal tibia plateau fracture (Schatzker 5) and due to swelling and blistering open reduction was delayed. By 7 days after injury open reduction and internal fixation was performed with bicolumnar plating. After 10 days both incisions dehisced and were debrided. Once the wounds were stable (10 days later) bilateral gastrocnemius flaps were performed. The flaps healed without any infection with union of fracture after 5 months. 


\section{OPERATIVE PROCEDURE}

After the bicolumnar fixation of the proximal tibia and bilateral wound dehiscence, the developed raw areas over medial and lateral aspect of tibia appears to be like a "Harlequin eye" (figure $7 \mathrm{~b}, \mathrm{c}$ ). The surgical technique for coverage of this soft tissue defect over an infected wound of the proximal tibia is as follows:

Patient is placed in a semi prone position (Figure 8). Under spinal anesthesia and tourniquet inflation, a midline approach is taken over the posterior aspect of the proximal leg.
Skin and fascia is dissected and the interval between the gastrocnemius and soleus is identified by blunt dissection. The medial and lateral heads of the gastrocnemius are incised at their distal tendinous ends and dissection carried out proximally with bipolar cautery. The vascular pedicle is visualized and protected. To gain extra length the aponeurosis is scored horizontally. Tourniquet is released and haemostasis achieved. Then patient is turned supine and defect covered with the flap and sutured with half.

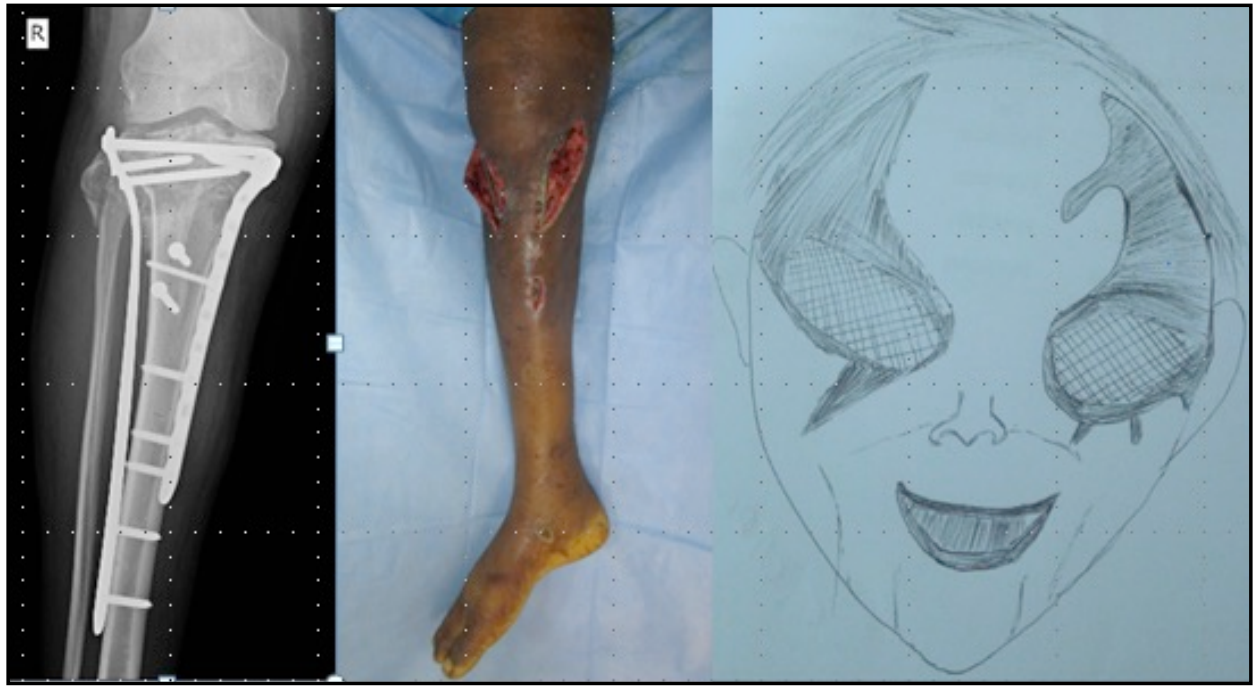

Figure 7: Shows the bicolumnar fixation and defect over proximal tibia medially and lateral.

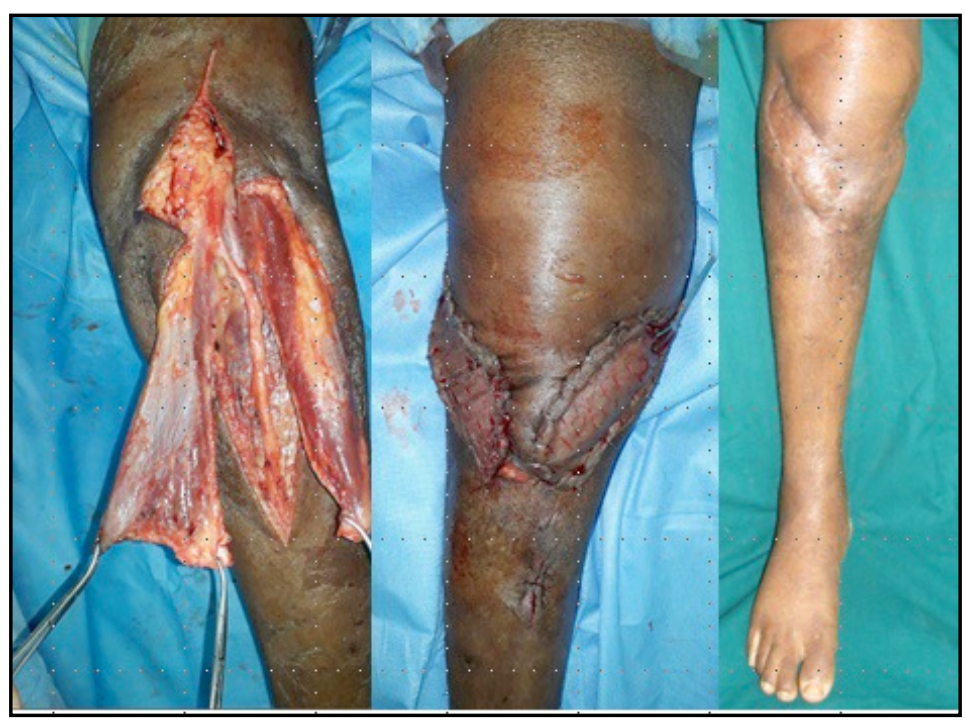

Figure 8: Shows patient in semi prone position both medial and lateral gastrocnemius muscleflap are raised simultaneously. Patient is turned supine and defect covered in one setting and skin grafting done, extreme right picture shows well settled flap after 2 weeks. 


\section{DISCUSSION}

Operative treatment of complex tibial plateau fractures remains controversial as there is considerable debate regarding best way to fix these type of fractures. Schatztker V and VI require bicolumnar plating with dual incision as it requires direct visualization for articular reconstruction. ${ }^{1}$ Dual incision technique has a high rate of soft tissue complications in past series with infection rates from $23 \%$ to $100 \% .^{2}$ Barie et al reported complications after dual incision technique with 8.4 percent deep infections in there series of 83 fractures. ${ }^{3}$ In a retrospective review study by Moore et al they had similar infection rates of around 13.8 percent as compared to recent studies. ${ }^{4}$ Dual incision are necessary for certain fracture patterns but it has known wound complications.

In a study by Yong et al on displaced proximal tibial fractures treated by open reduction, infection occurred in 6 of 19 (Schatzker type II) fractures $(32 \%)$ and in 7 of 8 (Schatzker type IV) fractures, it shows that that increasing complexity of fracture will lead to more soft tissue complications. ${ }^{5}$ Yang et al in a study of 44 metaphyseal fractures of the proximal tibia (Schatzker type VI) had six deep infections $(13.63 \%) .6,7$

Gastrocnemius flap is the workhorse flap for coverage of proximal tibia defect and if both heads are used then it can cover both medial and lateral side defects in same setting. Wei et al has described that use of pedicled medial and lateral gastrocnemius muscle flaps for covering a large exposed area of bone in a case of extensive necrosis following a lateral tibial osteotomy. Wound complications following dual incision for complex tibial fractures can be managed with timely intervention, debridement and bilateral gastrocnemius flaps. ${ }^{7-10}$.

\section{CONCLUSION}

This is an efficient technique that can solve a very complicated problem of soft tissue defect over both medial and lateral surface of proximal tibia following infection after internal fixation with plates and screws as these defects extends on either side of tibia and no local skin flap option available. Raising lateral gastrocnemius from front is difficult to reach the defect from front as cannot be adequately mobilized. After dividing the origin of both gastrocnemius which is easy from posterior midline excellent mobilization is possible.

\section{DECLARATION OF PATIENT CONSENT}

Authors certify that they have obtained all appropriate patient consent forms. In the form the patient(s) has/have given his/her/their consent for his/her/their images and other clinical information to be reported in the journal. The patients understand that their names and initials will not be published and due efforts will be made to conceal their identity, but anonymity cannot be guaranteed

\section{FINANCIAL SUPPORT AND SPONSORSHIP}

Nil.

\section{CONFLICTS OF INTEREST}

There are no conflicts of interest

\section{Corresponding author :}

Hari Venkatramani, MCh (Plast).

Department of Plastic Surgery, Ganga Medical Centre and Hospitals,313, Mettupalayam Road, Coimbatore, Tamil Nadu, India drhariv@gmail.com 


\section{REFERENCES}

1. Mills WJ, Nork SE. Open reduction and internal fixation of high-energy tibial plateau fractures. J Orthop Trauma. 2004 Nov-Dec;18(10):649-57

2. Chan C, Keating J. Comparison of outcomes of operatively treated bicondylar tibial plateau fractures by external fixation and internal fixation. Malays Orthop $J$. 2012;6(1):7-12. doi:10.5704/MOJ.1203.006.

3. Barei DP, Nork SE, Mills WJ, et al. Complications associated with internal fixation of high-energy bicondylar tibial plateau fractures utilizing a two-incision technique. J Orthop Trauma. 2004 NovDec;18(10):649-57.

4. Moore TM, Patzakis MJ, Harvey JP. Tibial plateau fractures: Definition, demographics, treatment rationale, and long-term results of closed traction management or operative reduction. J Orthop Trauma. 1987;1(2):97-119

5. Yang EC, Weiner L, Strauss E, et al. Metaphyseal dissociation fractures of the proximal tibia. An analysis of treatment and complications. Am J Orthop. 1995 Sep;24(9):695-704

6. Tetreault MW, Della Valle CJ, Hellman MD, Wysocki RW. Medial Gastrocnemius Flap in the Course of Treatment for an Infection at the Site of a Total Knee Arthroplasty. JBJS Essent Surg Tech. 2017;7(2):e14. Published 2017 May 10. doi:10.2106/JBJS.ST.17.00005

7. Young MJ, Barrack RL. Complications of internal fixation of tibial plateau fractures. Orthop Rev. 1994 Feb;23(2):149-54

8. Fu chan wei, Flaps and reconstructive surgery. China: Elsevier; 2009. Chapter 30:Gastrocnemius flap; Page410.

9. Rao J, Tawar R, Dawar R. Gastrocnemius Myocutaneous Flap: A Versatile Option to Cover the Defect of Upper and Middle Third Leg. World J Plast Surg. 2018;7(3):314-318. doi:10.29252/wjps.7.3.314.

10. Panse N, Bhadgale R, Karanjkar A, Phulwer R, Sahasrabudhe P, Ramteke C. The Reach of the Gastrocnemius Musculocutaneous Flap: How High Is High?. World J Plast Surg. 2018;7(3):319-325. doi:10.29252/wjps.7.3.319. 